Disorders (1978), Benzodiazepines Today and Tomorrow (1980), Depression and Anxiety (1992), Mental Illness in Pregnancy and the Puerperium (1978) and The Psychosomatic Approach: Contemporary Practice of Whole Person Care (1986).

During his career he received a number of awards, including the Gutheil-Von Domarus Award of the Association for the Advancement of Psychotherapy, the Doris Odlum Award of the BMA, and the A.E. Bennett Research Award of the Society for Biological Psychiatry of the USA.

Robin was born and brought up in Westcliff-on-Sea, in south-east England. His father died when he was 12 years old and his mother, a midwife, brought up her two sons on her own thereafter in straitened circumstances. He attended Westcliff High School for Boys, where our friendship of over 70 years began. From there he went to University College Hospital Medical School, London, graduating in 1956, having already married Marilyn in 1955. After house jobs, he signed up for a 3-year commission in the Royal Army Medical Corps. In the course of his service he was posted to the Far East.

After military service, Robin was appointed Lecturer in Psychiatry at the University of Edinburgh from 1964 to 1967. In 1966, he was Exchange Lecturer at the University of Chicago, where he made many lifelong friends. While there he carried out a survey of the psychiatric status of homeless people living on the streets. This formed the basis of his MD thesis (1970). On his return to the UK, he was appointed Senior Lecturer at St Georges' Hospital Medical School, London, where he worked from 1967 to 1973. From there he was appointed Professor of Psychiatry at St Mary's Hospital Medical School, London.

Robin had a wide range of interests. He enjoyed family tennis and, over many years, played squash regularly with a colleague. He took a close interest in his garden, taking especial pride in the Magnolia grandiflora on his lawn. He was fascinated by pond life, newts and snails. He was a keen theatre-goer and followed Essex, his home county cricket team, through their ups and downs. He enjoyed travel, with a special affection for France as well as Malaysia, particularly Penang, where he had been posted during his Army Service.

For several years before he died Robin suffered from cardiac amyloidosis. He became slowly and progressively less mobile until finally he was admitted to an excellent care home, where he died a few days after his 85th birthday. His wife, Marilyn, died less than a year before he did. He is survived by two sons, two grandchildren and two great-grandchildren.

\section{Jack Steinert}

doi:10.1192/bjb.2019.54

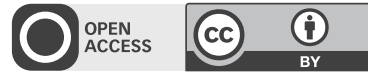

(c) The Author 2019. This is an Open Access article, distributed under the terms of the Creative Commons Attribution licence (http://creativecommons.org/ licenses/by/4.0/), which permits unrestricted re-use, distribution, and reproduction in any medium, provided the original work is properly cited.

\section{Alec Coppen, FRCPsych (Hon), MD, DSc}

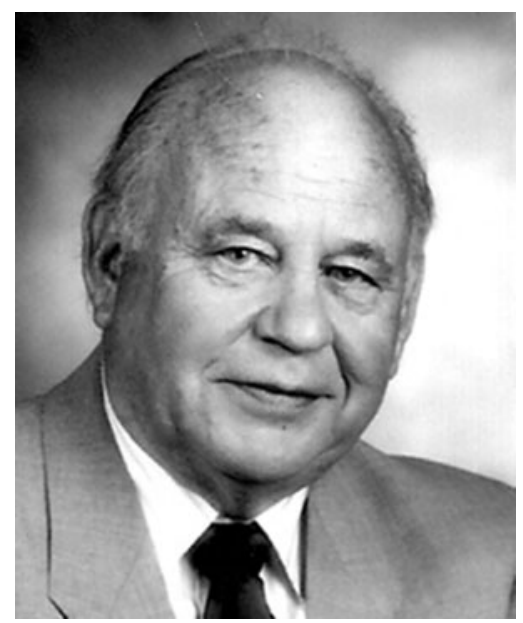

Alec Coppen, who died recently at the age of 96 , was a leading figure for over 50 years in the study of affective disorders using chemical and psychopharmacological approaches. This was in the era before brain imaging was possible. In a highly productive career, he carried out studies of electrolytes, tryptophan, serotonin metabolites and platelet transport. He was a pioneer of the serotonin theory of depression, which was to have such a key influence in the evolution of antidepressant drug treatment. He was also one of the first to use lithium in bipolar and affective disorders and carried out an important controlled trial of its effectiveness. From his own clinical work, he identified the particular ability of lithium to diminish suicide rates among people with severe affective illness, an observation amply confirmed by subsequent controlled trials and meta-analyses. He also had an interest in the role of folic acid in depression, finding evidence of deficiency and improvement with supplementation. He was one of the few psychiatrists with biochemical research skills.

Alec attended Dulwich College, London, after which he volunteered for military service in 1942 . He served in a commando regiment. In 1943, he nearly died from septicaemia and was one of the first people to be treated with penicillin. After the war, he studied medicine at the University of Bristol. He worked at the Maudsley Hospital, London, and in the Medical Research Council (MRC) Neuropsychiatry Unit, before becoming a member of the MRC external scientific staff. He built up his own research laboratory at West Park Hospital, a mental hospital in Epsom, where he worked until retirement. He trained many young psychiatrists in biological psychiatry, both British and from overseas, many of whom later went on to distinguished careers.

His career earned him much recognition and many roles in international organisations. He won the Anna-Monika Prize for biological psychiatry research, as well as various other awards and prizes. He was awarded honorary membership of many overseas psychiatric organisations. He was an early President of the British Association for Psychopharmacology and later President of the Collegium Internationale Neuropsycho-pharmacologicum (CINP), of which he was also an Honorary Fellow and recipient of a Pioneer Award. 
Alec was born in Streatham, London, in January 1923. He was the youngest of three sons of Herbert and Marguerite Coppen. His father came from a humble working-class background, eventually rising to be a senior accountant/manager and trouble-shooter for the United Africa Corporation - the forerunner of Unilever.

Alec was married in 1952 to Gunhild (Gunni) Andersson, who came from Sweden where she was studying English Literature at Lund University. They met when she was attending a summer course in Bristol and accommodated in a student hostel in which Alec was resident as a medical student. As a married couple they were inseparable at conferences in Britain and overseas. The Coppens lived in Epsom and were members of the nearby RAC country club, where they hospitably lunched or dined many visitors. They had a wide circle of friends, including many from Sweden, and spent time every summer at Gunni's summer house in south-west Sweden.

\section{Review}

\section{Stay With Me}

By Ayobami Adebayo

Canongate. 2017. £14.99 (hb). 304 pp.

ISBN 9781782119463

doi:10.1192/bjb.2019.57

From the mid-1980s till just before the turn of the 20th century, Nigeria was ruled by a succession of military dictators. This period has captured the imagination of a generation of young Nigerian writers. Stay with Me, a product of those times, adopts a novel writing formula that has been shown to yield great dividends - pick a period of political upheaval and set a love story against it. The ancient Yoruba myths of The Tortoise and Olurombi, which form the matrix for the novel, both centre on the lengths to which an African woman would go to have children.

A culture in which female barrenness is seen as a curse is ready fodder for psychopathologies, from mood disorders to anxiety and other illnesses. One such pathology, as seen in Stay with Me, is pseudocyesis. This concept (the name attributed to John Mason Good in 1823, from pseudes, meaning false, and kyesis, meaning pregnancy) has been known since antiquity. Pseudocyesis is the false belief of pregnancy that is associated with objective signs and reported symptoms of being pregnant. Physiological manifestations of pseudocyesis include irregular menstruation, abdominal distension, a subjective sensation of fetal movement, changes in breast size and shape, nausea and vomiting. All of these are experienced by Yejide, the novel's heroine.

The novel focuses on the psychosocial origins of pseudocyesis, emphasising the context of infertility, the
Alec was a short, genial, friendly and cultured man, and an opera lover. The Coppens were regular attenders at London's Covent Garden. He was both a friend and colleague of many leading psychiatrists and neuroscientists, including two Nobel Laureates, Arvid Carlson and Julius Axelrod.

Gunni died in 2007. They had one child, Michael, who is now a retired histopathologist.

\section{Eugene Paykel}

doi:10.1192/bjb.2019.55

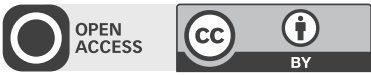

(c) The Author 2019. This is an Open Access article, distributed under the terms of the Creative Commons Attribution licence (http://creativecommons.org/ licenses/by/4.0/), which permits unrestricted re-use, distribution, and reproduction in any medium, provided the original work is properly cited.

personal grief of the protagonist, the feelings of insecurity, frustration and accompanying social stigma and the potential for infidelity as a remedy. There is some evidence that the early loss of a mother or polygamy may provide context for pseudocyesis; both of which are present in Yejide. Attribution to bewitchment and other cosmic forces often leads to seeking help from non-traditional (spiritual) sources, part of Yejide's pathway to care.

The theme of infidelity is illustrated by the protagonist's adultery with her brother-in-law. This aspect of the novel requires a degree of suspending disbelief, but it ultimately does not adversely affect our enjoyment of the passage in which all is revealed and 'the fires of hell overflowed their banks and spilled into [their] bedroom'.

Staying with the theme of false pregnancy, we are reminded of an excerpt from Plato's Timaeus: 'The womb is an animal which longs to generate children. When it remains barren for too long after puberty it is distressed and sorely disturbed, and straying about in the body.... Despite the improbability of this statement and its obvious patriarchal sentiment, the sense of it continues to generate topics for fiction, as demonstrated by this novel.

Niran Okewole, Senior Consultant Psychiatrist, Medical Services, Neuropsychiatric Hospital Aro, Abeokuta, Nigeria. Email: niranokewole@ gmail.com

doi:10.1192/bjb.2019.57

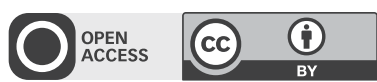

(c) The Author 2019. This is an Open Access article, distributed under the terms of the Creative Commons Attribution licence (http://creativecommons.org/ licenses/by/4.0/), which permits unrestricted re-use, distribution, and reproduction in any medium, provided the original work is properly cited. 